\title{
INTERPRETASI METODE MAGNETIK UNTUK PENENTUAN \\ STRUKTUR BAWAH PERMUKAAN DI SEKITAR GUNUNG KELUD KABUPATEN KEDIRI
}

\author{
Bagus Jaya Santosa, Mashuri, Wahyu Tri Sutrisno, \\ Abdurrahman Wafi, Riski Salim, Radhiyullah Armi \\ Jurusan Fisika \\ Institut Teknologi Sepuluh Nopember (ITS) Surabaya \\ Kampus ITS Sukolilo Surabaya 60111 \\ bjs@physics.its.ac.id
}

\begin{abstract}
Abstrak
Telah dilakukan pengukuran dengan metode magnetik untuk mengetahui struktur bawah permukaan di sekitar gunung kelud. Pengambilan data dilakukan secara acak pada area seluas 0,6 km $x 1 \mathrm{~km}$ dengan jumlah titik yang diperoleh 244 titik ukur. Proses akusisi dilakukan dengan menggunakan Magnetometer Proton ENVI SCINTREX. Pengolahan data diawali dengan koreksi IGRF dan koreksi variasi harian untuk mendapatkan anomali medan magnet total. Kemudian reduksi bidang datar, kontinuasi ke atas pada ketinggian 100 meter hingga 400 meter di atas sferoida referensi dan hasilnya digunakan untuk pemisahan anomali lokal dan regional. Hasil interpretasi kualitatif menunjukkan adanya anomali dipole magnetik di sebelah timur yang membentang dari arah barat laut ke tenggara sebesar -2125 $n T$ hingga 1863 nT. Metode Talwani 2-D digunakan untuk interpretasi kuantitatif. Model geologi yang dihasilkan adalah patahan atau sesar. Nilai suseptibilitas magnetik di bawah kubah kawah gunung kelud sampai ke gunung lirang ( $k=0,0124$ emu/gram) didominasi batuan basalt, dan di gunung sumbing ( $k=0,0234$ emu/gram - 0,0239 emu/gram) yang didominasi batuan andesit.
\end{abstract}

Kata kunci : anomali magnetik total, gunung kelud, struktur bawah permukaan dan suseptibilitas batuan, grinding 


\section{Pendahuluan}

Setiap peristiwa keluarnya magma Gunung Kelud pada tahun 2007 yang membentuk anak gunung adalah merupakan deformasi dari tubuh gunungapi. Peristiwa deformasi ini dapat berupa inflasi ataupun deflasi. Deformasi yang berupa inflasi umumnya terjadi karena proses gerakan magma ke permukaan yang menekan permukaan tanah di atasnya. Dalam hal ini deformasi yang maksimal biasanya teramati tidak lama sebelum letusan gunungapi berlangsung. Sedangkan deformasi berupa deflasi umumnya terjadi selama atau sesudah masa letusan.

Perubahan struktur di bawah permukaan bumi terjadi akibat perubahan beban massa tanah dan batuan baik di permukaan bumi maupun di dalam bumi, dalam peristiwa keluarnya magma Gunung Kelud. Untuk mengidentifikasi struktur bawah permukaan akibat peristiwa tersebut, dapat digunakan beberapa metode geofisika. Metode geofisika yang sering digunakan untuk menyelidiki struktur bawah permukaan antara lain: metode geolistrik, metode gaya berat, metode seismik dan metode geomagnet atau magnetik. Penelitian ini menggunakan metode magnetik karena telah banyak digunakan dalam eksplorasi mineral dan batuan. Metode magnetik dapat digunakan untuk menentukan struktur geologi besar bawah permukaan seperti sesar, lipatan, intrusi batuan beku atau kubah garam dan reservoir geothermal. Menurut metode magnetik dapat digunakan untuk mengetahui kedalaman dan struktur permukaan, pengukuran dapat diperoleh dengan mudah untuk studi lokal dan regional. Metode magnetik bekerja didasarkan pada pengukuran variasi kecil intensitas medan magnetik di permukaan bumi. Variasi ini disebabkan oleh kontras sifat kemagnetan antar batuan di dalam kerak bumi, sehingga menimbulkan medan magnet bumi yang tidak homogen, bisa disebut juga sebagai suatu anomali magnetik.

\section{Teori}

\subsection{Morfologi Daerah Penelitian}

Gunung Kelud(70.56، S dan 112.019’ E ) merupakan salah satu gunung api kuarter yang berkembang di Jawa Timur. Gunung Kelud dikelilingi oleh beberapa gunung api yang lebih tua, seperti Gunung Kawi dan Gunung Butak di sebelah timur, serta Gunung Anjasmara di sebelah timur laut. Gunung-gunung tersebut membentuk morfologi kasar dengan bukit, dan jurang yang terjal di timur laut dan di lereng Gunung Kelud. Menurut morfologi Gunung Kelud dapat dibagi menjadi 5 unit, yaitu puncak dan kawah Gunung Kelud, badan Kelud, cekungan parasitik Kelud, kaki dan dataran Kelud. Gunung Kelud mempunyai ketinggian lebih dari 1731 meter dpl, dan mempunyai morfologi yang tidak teratur. Hal ini disebabkan adanya erupsi yang bersifat eksplosif yang diikuti pembentukan kubah lava.

Stratigrafi dari satuan batuan Gunung Kelud terdiri dari berbagai macam aliran lava, kubah lava, aliran piroklastik dan timbunan piroklastik lembut. Batuan prakelud terdiri dari batuan vulkanik dari pegunungan selatan, Gunung Anjasmara, Gunung Butak dan Gunung Kawi. Timbunan sekunder terdiri dari lahar dingin dan kolovium.

\subsection{Struktur Geologi Daerah Penelitian}

Struktur geologi Gunung Kelud terdiri dari beberapa kawah (Lirang, Gajahmungkur, Tumpak, Sumbing, Dargo, Gupit, Badak dan Kelud) dan terdapat 32 patahan normal. 
Kesepuluh kawah tersebut umurnya berurutan dari yang tertua hingga termuda dan merupakan pusat erupsi yang berpindah-pindah berlawanan arah jarum jam. Masing-masing erupsi menghasilkan batuan piroklastik, pada umumnya merusak sebagian kawah lama. Secara petrologis, batuan vulkanik Gunung Kelud dapat diklasifikasikan sebagai calc-alkaline dan berkembang dari $\mathrm{K}$ basal medium ke $\mathrm{K}$ andesit medium ( $\mathrm{SiO} 2=49 \%$ hingga 61 $\%)$. Menurut terdapat beberapa tipe gempa vulkanik tercatat selama berlangsungnya pemantauan seismicitas Gunung Kelud. Tipe-tipe VK-1, VK-2, VK-3, dan VK-4 ( $\mathrm{VK}=$ Volcanic Kelud) tercatat dengan interval waktu rambat gelombang S-P antara 1 sampai 4 sekon, dengan kandungan frekuensi sekitar 3 Hertz. Hal ini berarti hiposenter berada pada posisi yang cukup dekat dengan permukaan.

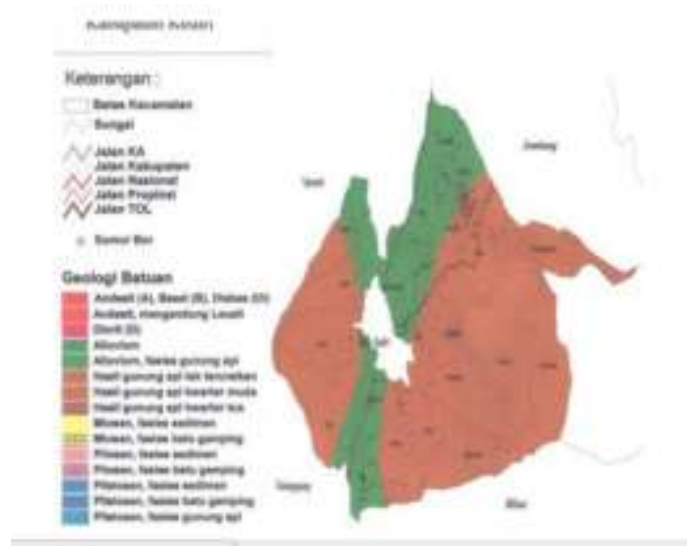

Gambar 2.1 Peta Geologi Kediri

\subsection{Medan Magnet}

Medan magnet bumi terkarakterisasi oleh parameter fisis atau disebut juga elemen medan magnet bumi, yang dapat diukur yaitu meliputi arah dan intensitas kemagnetannya. Parameter fisis tersebut meliputi :

- Deklinasi $(D)$, yaitu sudut antara utara magnetik dengan komponen horizontal yang dihitung dari utara menuju timur

- Inklinasi(I), yaitu sudut antara medan magnetik total dengan bidang horizontal yang dihitung dari bidang horizontal menuju bidang vertikal ke bawah.
- Intensitas Horizontal $(H)$, yaitu besar dari medan magnetik total pada bidang horizontal.

- Medan magnetik total $(F)$, yaitu besar dari vektor medan magnetik total.

Medan magnet utama bumi berubah terhadap waktu. Untuk menyeragamkan nilai-nilai medan utama magnet bumi, dibuat standar nilai yang disebut sebagai International Geomagnetics Reference Field (IGRF) yang diperbaharui setiap 5 tahun sekali. Nilai-nilai IGRF tersebut diperoleh dari hasil pengukuran rata-rata pada daerah luasan sekitar 1 juta $\mathrm{km}^{2}$ yang dilakukan dalam waktu satu tahun. Medan magnet bumi terdiri dari 3 bagian :

- Medan magnet utama (main field)

Medan magnet utama dapat didefinisikan sebagai medan rata-rata hasil pengukuran dalam jangka waktu yang cukup lama mencakup daerah dengan luas lebih dari $10^{6} \mathrm{~km}^{2}$.

- Medan magnet luar (external field)

Pengaruh medan magnet luar berasal dari pengaruh luar bumi yang merupakan hasil ionisasi di atmosfer yang ditimbulkan oleh sinar ultraviolet dari matahari. Karena sumber medan luar ini berhubungan dengan arus listrik yang mengalir dalam lapisan terionisasi di atmosfer, maka perubahan medan ini terhadap waktu jauh lebih cepat.

- Medan magnet anomali

Medan magnet anomali sering juga disebut medan magnet lokal (crustal field). Medan magnet ini dihasilkan oleh batuan yang mengandung mineral bermagnet seperti magnetite, titanomag-netite dan lain-lain yang berada di kerak bumi.

Dalam survei dengan metode magnetik yang menjadi target dari pengukuran adalah variasi medan magnetik yang terukur di permukaan (anomali magnetik). Secara garis besar anomali medan magnetik disebabkan oleh medan magnetik remanen dan medan magnetik induksi. Medan magnet remanen mempunyai peranan yang besar terhadap magnetisasi batuan yaitu pada besar dan arah medan 
magnetiknya serta berkaitan dengan peristiwa kemagnetan sebelumnya sehingga sangat rumit untuk diamati. Anomali yang diperoleh dari survei merupakan hasil gabungan medan magnetik remanen dan induksi, bila arah medan magnet remanen sama dengan arah medan magnet induksi maka anomalinya bertambah besar. Demikian pula sebaliknya. Dalam survei magnetik, efek medan remanen akan diabaikan apabila anomali medan magnetik kurang dari $25 \%$ medan magnet utama bumi (Telford, 1976),

\subsection{Metode Pengukuran Data Geomagnetik}

Dalam melakukan pengukuran geomagnetik, peralatan paling utama yang digunakan adalah magnetometer. Peralatan ini digunakan untuk mengukur kuat medan magnetik di lokasi survei. Salah satu jenisnya adalah Proton Precission Magnetometer (PPM) yang digunakan untuk mengukur nilai kuat medan magnetik total. Peralatan lain yang bersifat pendukung di dalam survei magnetik adalah Global Positioning System (GPS). Peralatan ini digunakan untuk mengukur posisi titik pengukuran yang meliputi bujur, lintang, ketinggian, dan waktu. GPS ini dalam penentuan posisi suatu titik lokasi menggunakan bantuan satelit. Digunakannya sinyal satelit karena menjangkau daerah yang sangat luas dan tidak terganggu oleh gunung, bukit, lembah dan jurang.

Beberapa peralatan penunjang lain yang sering digunakan di dalam survei magnetik, antara lain (Sehan, 2001) :

- Kompas geologi, untuk mengetahui arah utara dan selatan dari medan magnet bumi.

- Peta topografi, untuk menentukan rute perjalanan dan letak titik pengukuran pada saat survei magnetik di lokasi

- Sarana transportasi

- Buku kerja, untuk mencatat data-data selama pengambilan data
- PC atau laptop dengan software seperti Surfer, Matlab, Mag2DC, dan lain-lain.

Pengukuran data medan magnetik di lapangan dilakukan dengan menggunakan peralatan PPM, yang merupakan portable magnetometer. Data yang dicatat selama proses pengukuran adalah hari, tanggal, waktu, kuat medan magnetik, kondisi cuaca dan lingkungan.

Dalam melakukan akuisisi data magnetik yang pertama dilakukan adalah menentukan base station dan membuat station - station pengukuran (usahakan membentuk grid - grid). Ukuran gridnya disesuaikan dengan luasnya lokasi pengukuran, kemudian dilakukan pengukuran medan magnet di station station pengukuran di setiap lintasan, pada saat yang bersamaan pula dilakukan pengukuran variasi harian di base station.

\subsection{Pengolahan Data Geomagnetik}

Untuk memperoleh nilai anomali medan magnetik yang diinginkan, maka dilakukan koreksi terhadap data medan magnetik total hasil pengukuran pada setiap titik lokasi atau stasiun pengukuran, yang mencakup koreksi harian, IGRF dan topografi.

\subsubsection{Koreksi Harian}

Koreksi harian (diurnal correction) merupakan penyimpangan nilai medan magnetik bumi akibat adanya perbedaan waktu dan efek radiasi matahari dalam satu hari. Waktu yang dimaksudkan harus mengacu atau sesuai dengan waktu pengukuran data medan magnetik di setiap titik lokasi (stasiun pengukuran) yang akan dikoreksi. Apabila nilai variasi harian negatif, maka koreksi harian dilakukan dengan cara menambahkan nilai variasi harian yang terekan pada waktu tertentu terhadap data medan magnetik yang akan dikoreksi. Sebaliknya apabila variasi harian bernilai positif, maka koreksinya dilakukan dengan cara mengurangkan nilai variasi harian yang terekan pada waktu tertentu terhadap data medan magnetik 
yang akan dikoreksi, datap dituliskan dalam persamaan

$$
\Delta \mathrm{H}=\mathrm{H} \text { total } \pm \Delta \text { hharian }
$$

\subsubsection{Koreksi IGRF}

Data hasil pengukuran medan magnetik pada dasarnya adalah konstribusi dari tiga komponen dasar, yaitu medan magnetik utama bumi, medan magnetik luar dan medan anomali. Nilai medan magnetik utama tidak lain adalah niali IGRF. Jika nilai medan magnetik utama dihilangkan dengan koreksi harian, maka kontribusi medan magnetik utama dihilangkan dengan koreksi IGRF. Koreksi IGRFdapat dilakukan dengan cara mengurangkan nilai IGRF terhadap nilai medan magnetik total yang telah terkoreksi harian pada setiap titik pengukuran pada posisi geografis yang sesuai. Persamaan koreksinya (setelah dikoreksi harian) dapat dituliskan sebagai berikut :

$$
\Delta \mathrm{H}=\operatorname{Htotal} \pm \Delta \text { Hharian } \pm \mathrm{H} 0
$$

\section{Dimana H0 = IGRF}

\subsubsection{Koreksi Topografi}

Koreksi topografi dilakukan jika pengaruh topografi dalam survei megnetik sangat kuat. Koreksi topografi dalam survei geomagnetik tidak mempunyai aturan yang jelas. Salah satu metode untuk menentukan nilai koreksinya adalah dengan membangun suatu model topografi menggunakan pemodelan beberapa prisma segiempat (Suryanto, 1988). Ketika melakukan pemodelan, nilai suseptibilitas magnetik (k) batuan topografi harus diketahui, sehingga model topografi yang dibuat, menghasilkan nilai anomali medan magnetik ( $\Delta$ Htop) sesuai dengan fakta. Selanjutnya persamaan koreksinya (setelah dilakukan koreski harian dan IGRF) dapat dituliska sebagai

$$
\begin{gathered}
\Delta \mathrm{H}=\text { Htotal } \pm \Delta \text { Hharian }-\mathrm{H} 0- \\
\Delta \text { htop. }(2.2)
\end{gathered}
$$

Setelah semua koreksi dikenakan pada data-data medan magnetik yang terukur dilapangan, maka diperoleh data anomali medan magnetik total di topogafi. Untuk mengetahui pola anomali yang diperoleh, yang akan digunakan sebagai dasar dalam pendugaan model struktur geologi bawah permukaan yang mungkin, maka data anomali harus disajikan dalam bentuk peta kontur. Peta kontur terdiri dari garis-garis kontur yang menghubungkan titik-titik yang memiliki nilai anomali sama, yang diukur dar suatu bidang pembanding tertentu.

\subsection{Reduksi ke Bidang Data}

Untuk mempermudah proses pengolahan dan interpretasi data magnetik, maka data anomali medan magnetik total yang masih tersebar di topografi harus direduksi atau dibawa ke bidang datar. Proses transformasi ini mutlak dilakukan, karena proses pengolahan data berikutnya mensyaratkan input anomali medan magnetik yang terdistribusi pada biang datar. Beberapa teknik untuk mentransformasi data anomali medan magnetik ke bidang datar, antara lain : teknik sumber ekivalen (equivalent source), lapisan ekivalen (equivalent layer) dan pendekatan deret Taylor (Taylor series approximaion), dimana setiap teknik mempunyai kelebihan dan kekurangan (Blakely, 1995).

\subsection{Pengangkatan ke Atas}

Pengangkatan ke atas atau upward continuation merupakan proses transformasi data medan potensial dari suatu bidang datar ke bidang datar lainnya yang lebih tinggi. Pada pengolahan data geomagnetik, proses ini dapat berfungsi sebagai filter tapis rendah, yaitu unutk menghilangkan suatu mereduksi efek magnetik lokal yang berasal dari berbagai sumber benda magnetik yang tersebar di permukaan topografi yang tidak terkait dengan survei. Proses pengangkatan tidak boleh terlalu tinggi, karena ini dapat 
mereduksi anomali magnetik lokal yang bersumber dari benda magnetik atau struktur geologi yang menjadi target survei magnetik ini.

\subsection{Koreksi Efek Regional}

Dalam banyak kasus, data anomali medan magnetik yang menjadi target survei selalu bersuperposisi atau bercampur dengan anomali magnetik lain yang berasal dari sumber yang sangat dalam dan luas di bawah permukaan bumi. Anomali magnetik ini disebut sebagai anomali magnetik regional (Breiner, 1973). Untuk menginterpretasi anomali medan magnetik yang menjadi target survei, maka dilakukan koreksi efek regional, yang bertujuan untuk menghilangkan efek anomali magnetik regioanl dari data anomali medan magnetik hasil pengukuran.

Salah satu metode yang dapat digunakan untuk memperoleh anomali regional adalah pengangakatan ke atas hingga pada ketinggian-ketinggian tertentu, dimana peta kontur anomali yang dihasilkan sudah cenderung tetap dan tidak mengalami perubahan pola lagi ketika dilakukan pengangkatan yang lebih tinggi.

\subsection{Interpretasi Data Geomagnetik}

Secara umum interpretasi data geomagnetik terbagi menjadi dua, yaitu interpretasi kualitatif dan kuantitatif. Interpretasi kualitatif didasarkan pada pola kontur anomali medan magnetik yang bersumber dari distribusi benda-benda termagnetisasi atau struktur geologi bawah permukaan bumi. Selanjutnya pola anomali medan magnetik yang dihasilkan ditafsirkan berdasarkan informasi geologi setempat dalam bentuk distribusi benda magnetik atau struktur geologi, yang dijadikan dasar pendugaan terhadap keadaan geologi yang sebenarnya.

Interpretasi kuantitatif bertujuan untuk menentukan bentuk atau model dan kedalaman benda anomali atau strukutr geologi melalui pemodelan matematis.
Untuk melakukan interpretasi kuantitatif, ada beberapa cara dimana antara satu dengan lainnya mungkin berbeda, tergantung dari bentuk anomali yang diperoleh, sasaran yang dicapai dan ketelitian hasil pengukuran.

\section{Peralatan yang Digunakan}

Peralatan yang digunakan dalam pengolahan data ini adalah software microsoft excel, surfer9, MagPick, dan GravMag

\section{Metode Pengolahan Data}

Data yag digunakan adalah data dari sebuah thesis dari Zainul Musafak seorang mahasiswa pasca sarjana pada jurusan FISIKA FMIPA ITS. Dari data yang diperoleh dari thesis tersebut selanjutnya diolah kembali dengan menggunakan software tersebut di atas. Pertama data pada lampiran di masukkan dalam software microsoft excel untuk dirubah dalam format .xcel works. Kemudian dengan Surfer9 data tadi dibuka dan diolah guna mendapat surfer grid dan surfer plot. Setelah diolah dengan Surfer9 selanjutnya digunakan software MagPick untuk mengmabil penampangnya. Dari MagPick data dibuka dengan NotePad dan disimpan dalam file type .txt. Tahap terkahir adalah dengan mengolah data tadi dengan GravMag untuk mendapatkan penampang 2Dimensi dengan pendekatan.

\section{Pembahasan}

Berdasarkan metode di atas, berikut pembahasannya.

Data dari thesis tersebut di masukkan dalam software microsoft excel. Sehingga didapat data sebagai berikut: 


\begin{tabular}{|c|c|c|}
\hline $\mathrm{X}$ & & \\
\hline 43400 & 9122101 & \\
\hline 3391 & 22114 & \\
\hline 3385 & 22122 & \\
\hline 3377 & & \\
\hline 3370 & & \\
\hline 3366 & & \\
\hline 3360 & & \\
\hline 350 & & \\
\hline 344 & & \\
\hline 332 & & \\
\hline 321 & & \\
\hline 313 & & \\
\hline 307 & & \\
\hline 296 & & \\
\hline 282 & & \\
\hline 271 & 57 & \\
\hline 259 & 72 & \\
\hline 246 & & \\
\hline 238 & & \\
\hline 233 & & \\
\hline 3229 & & \\
\hline 21 & & \\
\hline 3221 & & \\
\hline 3221 & & \\
\hline 3221 & 9122347 & \\
\hline 3221 & 122351 & \\
\hline 3221 & 122355 & \\
\hline 3221 & 122363 & \\
\hline 3221 & & \\
\hline 3221 & & \\
\hline 3221 & & \\
\hline 32 & & \\
\hline & & \\
\hline & 9122429 & \\
\hline & & \\
\hline
\end{tabular}

Gamabar 5.1 data .xls

Dari data di atas kemudian di olah dalam software Surfer9 dan di dapat data .grid berikut,

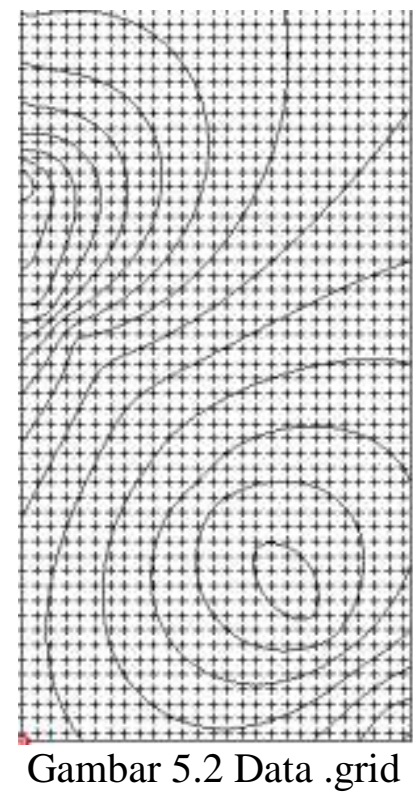

Dari data .grid itu selanjutnya diolah dengan software MagPick dan didapatkan plot data sejumlah 45 titik pick. Ke 45 data pick itu kemudian dikerjakan dalam software GravMag dan didapat gambar berikut,

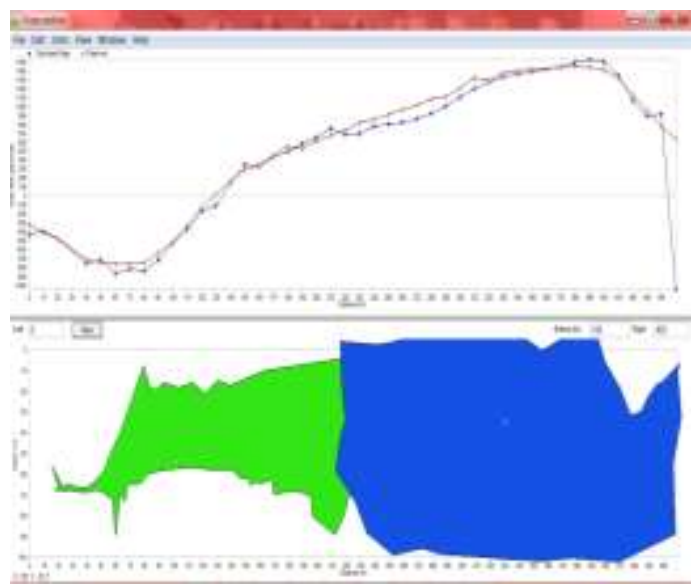

Gambar 5.3 hasil olah GravMag

Berdasarkan gambar 5.3 maka dilakukan sebuah interpretasi keadaan bawah tanah pada lokasi yang ditentukan.

Pada gambar 5.3 di atas, terlihat bahwa anomali terjadi pada jarak 328,933 meter dari titik E, pada data ke 27 dan berada pada sumbu x 643191, sumbu y 9122355 dengan medan magnet sebesar $-1335,8 \mathrm{nT}$.

Berdasarkan hasil permodelan GravMag tersebut, dapat diketahui bahwa, anomali 
magnetik pada sayatan E-F. Anomali didekat kubah kawah Gunung Kelud berupa patahan. Patahan ini, berupa anomali magnetik yang berbeda nilai suseptibilitasnya. Nilai suseptibilitas magnetik di bawah kubah kawah gunung Kelud dan sampai ke Gunung Lirang lebih rendah dari pada di bukit Gunung Sumbing. Secara umum, patahan suatu batuan memiliki nilai suseptibilitas yang sama. Perbedaan nilai suseptibilitas ini, diduga sebagai akibat dari demagnetisasi batuan yang terjadi di bawah Gunung Lirang. Demagnetisasi ini terjadi akibat batuan mengalami pemanasan sampai di atas suhu Curie. Berdasarkan hasil pemodelan data sayatan E-F, di ketahui bahwa nilai suseptibilitas magnetik di bawah Gunung Sumbing sebesar 0,0234 0,0239 emu/gram, sedangkan nilai suseptibilitas magnetic di bawah Gunung Lirang sebesar 0,0124 emu/gram. Nilai suseptibilitas batuan tersebut diduga sebagai batuan basalt dan andesit. Ini didukung oleh geologi gunung kelud didominasi oleh batuan basalt dan andesit.

Selanjutnya, dilakukan analisis terhadap titik potong antara sayatan E-F yang terletak pada posisi sumbu x 643233 dan sumbu y 9122315. Posis ini, pada sayatan E-F berwarna biru, dengan nilai suseptibilitas yang sama yaitu 0,0124 emu/gram. Hasil ini dikomparasikan terhadap hasil analisa data dengan menggunakan gradio vertikal, gradio horizontal sumbu $\mathrm{x}$, gradio horizontal sumbu y, dan reduksi ke kutub. Kesemua analisa tersebut, menguatkan dugaan bahwa adanya suplai lava dari Gunung Lirang ke kawah Gunung Kelud.

Pemodelan sayatan EF terdapat patahan, sehingga di dapatkan nilai suseptibilitas yang berbeda, Pada lempeng yang berwarna hijau memiliki nilai suseptibilitas 0,0239 emu/gram, lebar $200 \mathrm{~m}$ dan kedalamanya $30 \mathrm{~m}$ di bawah permukaan sampai batas bawah $85 \mathrm{~m}$. Pada lempeng yang berwarna biru memiliki nilai suseptibilitas 0,0124 emu/gram, lebar 190 $\mathrm{m}$ dan kedalaman $25 \mathrm{~m}$ di bawah permukan sampai batas bawah $90 \mathrm{~m}$. Lempeng warna biru memiliki nilai suseptibilitas yang lebih rendah, hal ini disebabkan pemanasan pada kawah gunung kelud.

\section{Kesimpulan}

Setelah melakukan akuisisi, pengolahan dan interpretasi data maka dapat disimpulkan bahwa:

1. Pada kontur medan magnet total yang dikoreksi variasi harian dan IGRF diperoleh dipole magnet yang menunjukkan adanya anomali di daerah penelitian. Anomali medan magnet total pada kontur menunjukkan pasangan closure positif dan negatif, dengan besar medan magnet pada closure positif sekitar $1851 \mathrm{nT}$ dan medan magnet closure negatif sekitar -2178 nT.

2. Dari peta kontur gradiomagnetik dan reduksi ke kutub dapat diketahui bahwa anomali magnetik memanjang dari gunung sumbing dan gunung Lirang menuju kawah gunung elud, anomali tersebut berupa magma gunung api.

3. Interpretasi kuantitatif menggunakan metode talwani 2D dengan memanfaatkan perangkat lunak GRAVMAG, pada sayatan E-F anomali terjadi pada jarak 328,933 meter dari titik E, pada datum ke 27 dan berada pada sumbu x 643191, sumbu y 9122355 dengan medan magnet sebesar $-1335,8 \mathrm{nT}$.

4. Interpretasi kuantitatif menggunakan metode talwani 2D dengan memanfaatkan perangkat lunak GRAVMAG, sayatan EF menghasilkan pendugaan geometri dua buah benda dibawah permukaan dengan tingkat kesalahan $0,85 \%$. Benda anomali I dengan nilai suseptibilitas 0,0239 emu/gram berada pada kedalaman puncak $30 \mathrm{~m}$ dan batas bawah $85 \mathrm{~m}$. Benda anomali II dengan nilai suseptibilitas $0,0124 \mathrm{emu} / \mathrm{gram}$, berada pada kedalaman puncak $25 \mathrm{~m}$ dan batas bawah $90 \mathrm{~m}$. 


\section{Daftar Pustaka}

Sharma, Prem. V. 1997 Environmental an Engineering Geophysics. Cambridge University Press.

Burger, H. R., Sheehan, A. F., dan Jones, C. H. (1992) Introduction to Applied Geophysic Exploring the Shallow Subsurface. W.W. Norton \& Company, New York.

Santoso, D. (2002) Pengantar Teknik Geofisika. Penerbit: ITB, Bandung.

Kirbani S.B dan Wahyudi. 2007. Erupsi Gunup Api Kelud dan Nilai-B Gempabumi di sekitarnya.

Jurnal Berkala MIPA UGM, 17(3), September.

Blakely, R.J., 1995, Potensial Theory in Gravity and Magnetic Applications, Cambridge University Press.
Pozza, M., Hrvoic, D. and Priddis, K.. 2003. Mapping Marine Ferrous Targets Using the SeaQuest Gradiometer System. Rev 1.0 (C) 2003 Marine Magnetics Corp.

Maryanto, S, Noviari, H, Musyarofah, N, Hidayati, S, dan Kriswati, E (2007) Seismisitas dan Deformasi Gunung Kelud Pada Pertumbuhan Kubah Lava Tahun 2007 . Malang : Jurusan Fisika FMIPA UNIBRA. http://www.mtech.edu/mines/geophysic al

/xzhou/GEOP4210_FieldGeology\& Geophysics.html.

Djumarma, A (1991) Some studies of volcanology,petrology and structure of Mt.Kelut,east Java,Indonesia,thesis. 